Research Article

\title{
Evaluation of knowledge, attitude and behavior about rational use of medicines in second year medical students
}

\author{
Smita D. Sontakke*, Ritu J. Budania, Shreekant G. Paranjape
}

\begin{abstract}
Department of Pharmacology, Govt. Medical College, Nagpur, M.S. 440003, India
\end{abstract}

Received: 29 July 2013

Accepted: 4 August 2013

*Correspondence to:

Dr. Smita D. Sontakke,

Email: smitaavanti@yahoo.co.in

(C) 2013 Sontakke SD et al. This

is an open-access article

distributed under the terms of

the Creative Commons

Attribution Non-Commercial

License, which permits

unrestricted non-commercial

use, distribution, and

reproduction in any medium,

provided the original work is

properly cited.

\begin{abstract}
Background: To assess the knowledge about various issues concerned with rational use of medicines in second year medical students

Methods: This was a survey-based, cross-sectional study in which a self developed, pre-tested, semi-structured questionnaire was used. Respondents were 153 students of second year MBBS (beginning of third semester). They were explained about nature and purpose of study and necessary consent obtained. Questions were framed to obtain information about various issues concerned with use of medicines, common beliefs /misconceptions, purchase of medicines, sources of information about medicines etc. Results were expressed as counts and percentages.
\end{abstract}

Results: Majority of respondents were aware about OTC (54\%) and generic medicines $(96.7 \%)$, importance of reading medicine label $(58.8 \%)$, that medicines are not needed for every illness $(86.2 \%)$, medicines manufactures by big multinational companies are not always better $(67.9 \%) .75 .8 \%$ respondents were not influenced by direct to consumer advertising for purchase of medicines and $69.9 \%$ opined that medicines obtained from government hospital are not of inferior quality. $83.6 \%$ of respondents opined that they never mixed treatment of more than one doctor at a time and $83 \%$ always purchased all medicines written in prescription. For $93.4 \%$ respondents' doctors' advice was the most important factor that influenced medicine purchase.

Conclusion: Though majority of respondents were aware about most of the issues addressed in the questionnaire which seems to be a positive finding, those still unaware needs to be educated by adopting suitable interventions.

Keywords: Rational use of drugs, KAP study, Awareness about RUM

\section{INTRODUCTION}

Any health care system needs to focus on three key aspects about medicines - access, affordability and rational use of medicines. ${ }^{1}$

Rational use of medicines (RUM) requires that "patients receive medications appropriate for their clinical needs, in doses that meet their own individual requirements, for an adequate period of time and at lowest cost for both the patients and their community". ${ }^{2}$

Irrational use of medicines is on the rise owing to factors such as misleading/false beliefs, inadequate knowledge on part of the consumers and prescribing pressures, professional, profit driven approach of prescribers, lucrative promotional activities by pharmaceutical industry and lack of enforcement of regulations by regulatory authorities. ${ }^{3}$ Consequently it leads to increased cost of treatment, wastage of resources, unwanted effects like adverse effects, anti-microbial resistance.

The first step to correcting irrational use of medicines is to measure it. To address the problem of irrational use of medicines, the health planners need specific information on the type of irrationality been practiced so that appropriate, effective and feasible strategies can be chosen.Various studies have evaluated the perception of RUM among different stakeholders viz; nurses, pharmacy students, pharmacists, prescribers. ${ }^{4-6}$ Medical students are future physicians and prescribers. It is important to know their perception about RUM as they can play an important role in addressing this problem in future. Hence, assessing their knowledge about this sensitive issue will help in identifying problem areas which need to be addressed and corrected. Most of the earlier studies in 
medical students have evaluated their knowledge about self-medication. $^{7-9}$ Some interventional studies have attempted to improve prescribing habits of medical students by employing various interventions ${ }^{10,11}$, but we did not come across any published study that has evaluated the different facets about RUM in medical students. Hence this study was conducted to evaluate the knowledge, attitude and practice about RUM in medical students.

\section{METHODS}

This was a survey-based, cross-sectional study carried out after obtaining approval from Institutional Ethics Committee. Study population included 153 students of second MBBS (third semester) of Government Medical College, Nagpur, India. They were explained about the study and their consent taken. Identity of the students was not revealed.

A self-developed, pre-validated, semi-structured questionnaire consisting of both open-ended and closedended items was used. Questionnaire was designed to obtain information about various issues concerned with RUM. The questionnaire was first pre-tested in five students and appropriate modifications done. Appropriate instructions about filling the questionnaire were given. The final version of the questionnaire was distributed to the participants. Data was expressed as counts and percentages. Graph pad prism software version 5.01 was used to analyze data.

\section{RESULTS}

153 students participated in the study out of which 69 were men and 84 women. Mean $( \pm$ SD) age of respondents was $19.26( \pm 0.7698)$ years.

Table 1 shows that majority of the respondents were aware about OTC medicines (56\%), and believed that it is not safe to take OTC medicines with prescription medicines $(56.3 \%)$. Majority were also aware that same generic content of medicines is available under different names $(96.8 \%)$ and there is variation in the prices of different brands of the same medicine $(93.4 \%)$. Not many were aware about precautions to be taken during online purchase of medicines (28.7\%). Most of the respondents were aware about precautions to be taken while using medicines in children (74.6\%), elderly $(66.66 \%)$, pregnant and breast feeding women (66\%). $81.6 \%$ respondents believed that any tablet can be divided for use in pediatric patients.

Table 2 shows that less number of respondents believed that costlier medicines are better than cheaper ones $(23.53 \%)$ or medicines manufactured by foreign multinational companies are better (27.45\%). Only $11.77 \%$ felt that medicine is needed for every illness and $7.18 \%$ believed that more the number of medicines in a prescription better \& earlier will be the relief. Only
$32.69 \%$ respondents thought that medicines from government hospitals are of inferior quality as compared to those from private pharmacies and $67.9 \%$ opined that gain by irrational prescribing is maximum to pharmaceutical industry. Majority of the respondents (86.2\%) opined that doctors cannot completely depend on information about medicines provided by representatives of pharmaceutical industry.

Table 1: Evaluation of respondents' knowledge about medicine use $(n=153)$.

\begin{tabular}{|c|c|c|c|c|}
\hline \multirow{2}{*}{$\begin{array}{l}\text { S. } \\
\text { No }\end{array}$} & \multirow{2}{*}{ Statement } & \multicolumn{3}{|c|}{ No. of respondents (\%) } \\
\hline & & Yes & No & NA \\
\hline 1 & $\begin{array}{l}\text { Aware about OTC } \\
\text { medicines }\end{array}$ & $86(56)$ & $64(41.8)$ & $3(1.9)$ \\
\hline 2 & $\begin{array}{l}\text { OTC can be safely } \\
\text { taken with } \\
\text { prescription } \\
\text { medicines }\end{array}$ & $52(33.9)$ & $86(56.3)$ & $15(9.8)$ \\
\hline 3 & $\begin{array}{l}\text { Aware that same } \\
\text { generic content of } \\
\text { medicines is } \\
\text { available under } \\
\text { different names }\end{array}$ & 148(96.8) & $5(3.2)$ & - \\
\hline 4 & $\begin{array}{l}\text { Aware that wide } \\
\text { variation in prices } \\
\text { of different brands } \\
\text { of same medicine }\end{array}$ & $143(93.4)$ & $10(6.5)$ & - \\
\hline 5 & $\begin{array}{l}\text { Aware about } \\
\text { precautions to be } \\
\text { followed during } \\
\text { online purchase of } \\
\text { medicines }\end{array}$ & $44(28.8)$ & $106(69.3)$ & $3(1.9)$ \\
\hline 6 & $\begin{array}{l}\text { Aware about } \\
\text { precautions to be } \\
\text { taken while using } \\
\text { medicines in } \\
\text { children }\end{array}$ & $114(74.6)$ & $35(22.8)$ & $4(2.6)$ \\
\hline 7 & $\begin{array}{l}\text { Aware about } \\
\text { precautions to be } \\
\text { taken while using } \\
\text { medicines in } \\
\text { pregnant and } \\
\text { breastfeeding } \\
\text { women }\end{array}$ & 101(66) & $49(32.02)$ & $3(1.98)$ \\
\hline 8 & $\begin{array}{l}\text { Aware about } \\
\text { precautions to be } \\
\text { taken while using } \\
\text { medicines in } \\
\text { elderly }\end{array}$ & $102(66.66)$ & $48(31.3)$ & $3(1.97)$ \\
\hline 9 & $\begin{array}{l}\text { Any tablet can be } \\
\text { divided for use in } \\
\text { paediatric patients }\end{array}$ & $125(81.6)$ & $23(15.13)$ & $5(3.27)$ \\
\hline 10 & $\begin{array}{l}\text { Aware about expiry } \\
\text { period (expiry date) } \\
\text { of medicines }\end{array}$ & $128(83.66)$ & $22(14.37)$ & $3(1.97)$ \\
\hline
\end{tabular}

Figures in parentheses indicate percentage 
Table 2: Evaluation of respondents' attitude about medicine use $(n=153)$.

\begin{tabular}{|c|c|c|c|c|}
\hline \multirow{2}{*}{$\begin{array}{l}\text { S. } \\
\text { No }\end{array}$} & \multirow{2}{*}{ Statement } & \multicolumn{3}{|c|}{ No. of respondents (\%) } \\
\hline & & Yes & No & $\begin{array}{l}\text { Not } \\
\text { aware }\end{array}$ \\
\hline 1 & $\begin{array}{l}\text { Costlier medicines } \\
\text { are better than } \\
\text { cheaper ones }\end{array}$ & $36(23.53)$ & $117(76.47)$ & - \\
\hline 2 & $\begin{array}{l}\text { Medicines } \\
\text { manufactured by } \\
\text { foreign } \\
\text { multinational } \\
\text { companies are } \\
\text { better }\end{array}$ & $42(27.45)$ & $98(64.05)$ & $13(8.5)$ \\
\hline 3 & $\begin{array}{l}\text { Medicine is } \\
\text { needed for every } \\
\text { illness }\end{array}$ & $18(11.77)$ & $134(87.58)$ & $1(0.65)$ \\
\hline 4 & $\begin{array}{l}\text { More the number } \\
\text { of medicines in a } \\
\text { prescription better } \\
\& \text { earlier will be } \\
\text { the relief }\end{array}$ & 11(7.18) & $140(91.5)$ & $2(1.32)$ \\
\hline 5 & $\begin{array}{l}\text { Medicines from } \\
\text { government } \\
\text { hospitals are of } \\
\text { inferior quality as } \\
\text { compared to those } \\
\text { from private } \\
\text { pharmacies }\end{array}$ & $50(32.69)$ & $102(66.66)$ & $1(0.65)$ \\
\hline 6 & $\begin{array}{l}\text { Doctors can } \\
\text { completely depend } \\
\text { on information } \\
\text { about medicines } \\
\text { provided by } \\
\text { Pharma industry }\end{array}$ & $19(12.4)$ & $132(86.2)$ & $2(1.4)$ \\
\hline 7 & $\begin{array}{l}\text { Gain by irrational } \\
\text { prescribing is } \\
\text { maximum to } \\
\text { pharma industry }\end{array}$ & $104(67.9)$ & $44(28.75)$ & $5(3.35)$ \\
\hline 8 & $\begin{array}{l}\text { Mass } \\
\text { communication is } \\
\text { a bad medium to } \\
\text { educate people } \\
\text { about medicines }\end{array}$ & $17(11.11)$ & $136(88.8)$ & - \\
\hline
\end{tabular}

Figures in parentheses indicate percentage

Table 3 shows that $58.8 \%$ respondents read label on OTC medicines before use. Very few respondents (13.7\%) admitted that they reused doctor's prescription for similar complaint in other person, purchased any medicines online $(3.93 \%)$ or purchased any medicines from sales person visiting their home (4.5\%). 93.4\% respondents purchase all medicines written in the prescription, $94.11 \%$ stick to doctor's advice and instructions and $67.97 \%$ consulted the doctor before stopping medicine.

For $93.4 \%$ respondents, doctors' advice was the most important factor that influenced medicine purchase. Other factors are listed below in Figure 1.
Only $4.5 \%$ respondents used books as source of information about medicines used for self-medication while others depended on other sources such as doctors' advice $(27.4 \%)$, family $(22.2 \%)$, pharmacist $(13 \%)$, mass media (8.4\%), and internet (5.8\%).

Table 3: Evaluation of practices of medicine use in respondents'

\begin{tabular}{|c|c|c|c|c|}
\hline \multirow{2}{*}{$\begin{array}{l}\text { S. } \\
\text { No }\end{array}$} & \multirow{2}{*}{ Statement } & \multicolumn{3}{|c|}{ No. of respondents (\%) } \\
\hline & & Yes & No & $\begin{array}{l}\text { Not } \\
\text { aware }\end{array}$ \\
\hline 1 & $\begin{array}{l}\text { Read label on OTC } \\
\text { medicines }\end{array}$ & $90(58.8)$ & $50(32)$ & $\begin{array}{l}13 \\
(8.48)\end{array}$ \\
\hline 2 & $\begin{array}{l}\text { Do you reuse } \\
\text { doctor's } \\
\text { prescription for } \\
\text { similar complaint } \\
\text { in other person }\end{array}$ & $21(13.7)$ & $\begin{array}{l}126 \\
(82.4)\end{array}$ & $6(3.9)$ \\
\hline 3 & $\begin{array}{l}\text { Purchase any } \\
\text { medicines Online }\end{array}$ & $6(3.93)$ & $\begin{array}{l}145 \\
(94.77)\end{array}$ & $2(1.3)$ \\
\hline 4 & $\begin{array}{l}\text { Purchase any } \\
\text { medicines from } \\
\text { direct to consumer } \\
\text { advertising }\end{array}$ & $34(22.22)$ & $\begin{array}{l}115 \\
(75.18)\end{array}$ & $4(2.6)$ \\
\hline 5 & $\begin{array}{l}\text { Mix treatment of } \\
\text { more than one } \\
\text { doctor at a time, } \\
\text { for same problem } \\
\text { without informing } \\
\text { them }\end{array}$ & 11(7.18) & $\begin{array}{l}126 \\
(82.35)\end{array}$ & $\begin{array}{l}16 \\
(10.45)\end{array}$ \\
\hline 6 & $\begin{array}{l}\text { Mix allopathic } \\
\text { treatment with } \\
\text { Ayurvedic/ } \\
\text { traditional home } \\
\text { remedy/ } \\
\text { homeopathy/ unani }\end{array}$ & $35(22.87)$ & $\begin{array}{l}79 \\
(51.63)\end{array}$ & $\begin{array}{l}39 \\
(25.49)\end{array}$ \\
\hline 7 & $\begin{array}{l}\text { Purchase all } \\
\text { medicines written } \\
\text { in prescription }\end{array}$ & $143(93.4)$ & $4(2.6)$ & $6(3.9)$ \\
\hline 8 & $\begin{array}{l}\text { Stick to doctor's } \\
\text { advice and } \\
\text { instructions }\end{array}$ & $144(94.11)$ & $1(0.65)$ & $8(5.22)$ \\
\hline 9 & $\begin{array}{l}\text { Consult the doctor } \\
\text { before stopping } \\
\text { medicine }\end{array}$ & $104(67.97)$ & $\begin{array}{l}24 \\
(15.68)\end{array}$ & $\begin{array}{l}25 \\
(16.33)\end{array}$ \\
\hline
\end{tabular}

Figures in parentheses indicate percentage

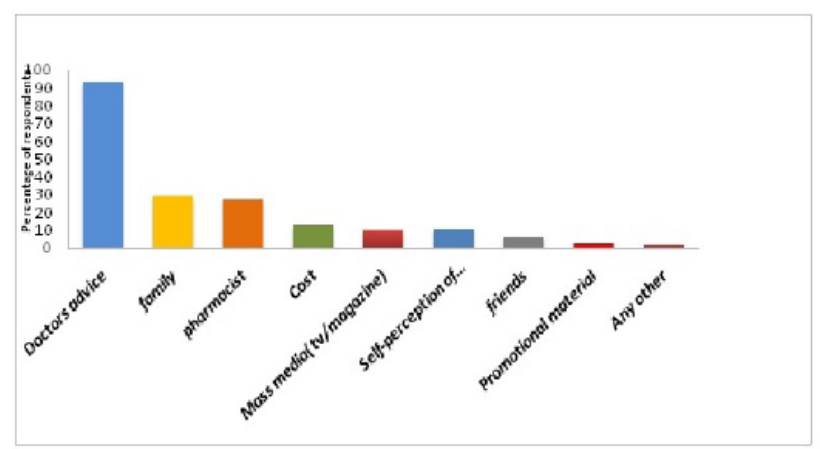

Figure 1: Factors influencing purchase of medicines. 


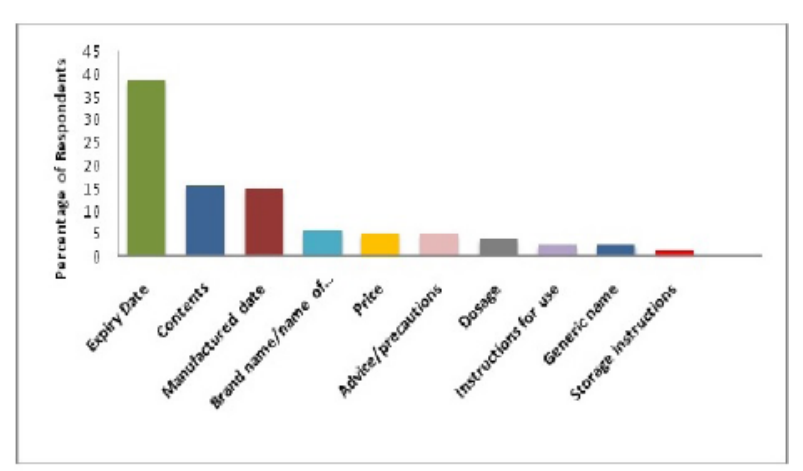

Figure 2: Information read from medicine labels.

\section{DISCUSSION}

National Rural Health Mission in agreement with WHO recommends that incorporation of Rational drug use in under graduate medical curriculum should be one of the interventions of Rational Drug Use policy. ${ }^{1}$ Training in Rational use of medicines is more likely to be effective if it takes into consideration students' existing knowledge, outlook and expertise and is targeted to the prescribing requirements in future. ${ }^{2}$ Any such intervention would require to have an understanding of the students' awareness about various issues concerned with RUM. This being their learning stage, they are most vulnerable to getting influenced by various factors which can affect their perception either positively or otherwise.

This study evaluates knowledge, attitude and practice about RUM in second year (third semester) medical students. Majority of respondents were aware about most of the issues addressed in the questionnaire which seems to be a positive finding. But being future prescribers all of them need to have correct knowledge about all the issues addressed. Hence, it is important that those still unaware should be educated by adopting suitable interventions. $33.9 \%$ respondents believed that OTC medicines can be safely taken with prescription medicines. Though this may be true for some of the OTC medicines but such a generalized statement cannot be true particularly in a country where, barring a few exceptions, almost any medicine is available without a prescription. Future doctors need to be aware of this scenario and hence it is important to emphasize upon them that any medicine procured without a prescription cannot be always safe particularly if the patient is already on treatment with some prescription medicine and hence, any OTC medicine should be taken only after consulting the doctor.

It was surprising to know that majority of respondents $(81.6 \%)$ were not aware that any tablet cannot be broken into parts for use in pediatric patients. Though knowledge about such issues is a part of the practical curriculum, the unawareness may be because the respondents were third semester students who had not yet completed the practical training. But this reflects the view of the society in general and it is the doctors'/ pharmacists' duty to educate patients about the same. This can be considered a major misconception as many tablets which should not be broken before use can lose their efficacy if taken in such a manner.

It was encouraging to know that most of the respondents were aware about issues such as availability of generic and branded medicines, wide difference in the prices of different brands, polypharmacy not always being useful. But it is important that these concepts remain in their minds till they start prescribing and actually implement them in their practice. This would be possible only when all these issues are repeatedly reinforced upon them and also when they are made aware about the serious consequences of irrational prescribing.

In this study majority of the respondents seem to be aware that doctors should not totally depend on information about medicines provided by Pharmaceutical industry and that gain by irrational prescribing is maximum to pharma industry. Though this is a positive finding it is really difficult to assess how many of these respondents would really follow this in actual practice as the means adopted by the Pharmaceutical industry to lure prescribers are so appealing that it is often very difficult for them to resist and so they easily fall prey to these gimmicks. This problem which is one of the major contributor to irrational drug use can be resolved only if the prescriber is self-motivated and dedicated towards the cause of patient care. Repeatedly reminding the medical students about this by way of appropriate inclusions in the medical curriculum can be helpful to a certain extent.

Regarding practice of RUM, majority of respondents seemed to adopt rational practices such as not reusing doctor's prescription for similar complaint in other person, not mixing treatment of more than one doctor at a time, for same problem without informing them, purchasing all medicines written in prescription, following doctor's advice and instructions. Only 58.8\% respondents admitted to reading the medicine label before use and only $2.6 \%$ read the generic name of the medicine. This is not an encouraging finding and needs to be corrected since using/prescribing medicines by generic names is an important measure in promoting RUM.

Most of the issues addressed in this study are about the concepts prevalent in the general public which is the major consumer of medicines. Correcting any prevailing misconception is the responsibility of the health care providers (doctors, nurses, pharmacists). Since medical students are future doctors any false beliefs/ misconceptions about various issues pertaining to medicine use amongst them need to be corrected. Public education is important for proper use of medicines because people do not have the expertise and knowledge about use of medicines and are not aware about the pros and cons of medicine use. Doctors can play a major role in patient education. To educate the patients, doctors themselves must be well versed with various issues concerned with RUM, should not have any 
misconceptions or false beliefs. This is possible only when medical students are sensitized to these issues during their learning phase by proper training and the same is emphasized upon them repeatedly. The conventional system of medical education focuses mainly on inculcating more and more information. Though it is now a well-accepted fact that RUM is an important issue and that doctors are the major prescribers of medicines, teaching of RUM is not given much importance in most of the medical colleges. ${ }^{10}$ This can be considered as a major cause of errors in prescribing with its adverse consequences subsequently. ${ }^{12-14}$

Teaching hospitals should consider that promoting RUM is their moral duty towards humanity, which they can do through their teaching staff who can most effectively imbibe this concept into the minds of future doctors. Since medical students are at the stage of learning where their understanding and outlook are subject to change, any new concept to which they are exposed is more likely to be accepted and retained. This study provides an insight into the perception of various aspects of RUM in future doctors which would be helpful in planning an intervention targeting this group which can be considered one of the major stakeholders in rational drug use.

\section{CONCLUSION}

Majority of students were aware about various issues concerned with RUM. But considering the fact that the respondents are future prescribers all of them need to be aware about all the aspects related to RUM. Inadequate/improper knowledge in certain areas is a matter of concern and needs to be addressed. Though training in RUM is a part of undergraduate medical curriculum in most of the medical universities the same should be made more vigorous to empower the future doctors to prescribe and practice rationally.

\section{Funding: None}

Conflict of interest: None declared

Ethical approval: The study was approved by the institutional ethical committee

\section{REFERENCES}

1. Sharma S. Promoting Rational drug use under National Rural Health Mission, National Health Resources centre. Ministry of Health and Family Welfare, Government of India 2009;5-7.

2. World Health Organisation: Guide to Good Prescribing, Geneva. World Health Organisation 1994;101-3.
3. Holloway K. Promoting rational use of medicines. Contact a publication of world council of churches 2006;183:2-3.

4. Toklu HZ, Demirdamar R, Gümüşel B, Ersin Yarış E, Dülger G. Rational drug use awareness of the nurses in the turkish republic of northern cyprus near east university hospital. Marmara Pharmaceutical Journal 2012;16:150-4.

5. Kunda G, Thawani V, Sontakke S, Chaudhari K, Bankar M, Diwe R. Effect of information, education and communication intervention on awareness about rational pharmacy practice in pharmacy students. Indian Journal of Pharmacology 2011;43 (4):381-4.

6. Sankaravadivu T, Kumar SE, Bhavya E. A prospective study on rational drug use and the essential drug concept. International Journal of Research in Pharmaceutical and Biomedical Sciences 2011;2(2):503-6.

7. Henry J, Handu SS, Khalid AJ, Khaja ASO, Sequeira RP. Evaluation of the knowledge, attitude and practice of self-medication among first-year medical students. Med Princ Pract 2006;15:270-5.

8. James H, Handu SS, Khaja KA, Sequeira RP. Influence of medical training on self-medication by students. Int $\mathbf{J}$ Clin Pharmacol Ther 2008;46(1):23-9.

9. Sontakke SD, Bajait CS, Pimpalkhute SA, Jaiswal KM, Jaiswal SR. Comparative study of evaluation of self-medication practices in first and third year medical students. Int J Biol Med Res 2011;2(2):561-4.

10. Patrício KP, Borges Alves NA, Arenales NG, Queluz TT. Teaching the rational use of medicines to medical students: a qualitative research. BMC Medical Education 2012;12:56.

11. De-Sousa F, Andressa B, Fernanda B, Fernandes MS. Rational use of medicines report of an experience in medical education at unesc criciúma, santa catarina state, brazil. Rev Bras Educ Med. [online] 2010;34(3):438-45.

12. World Health Organization: Selection and rational use of medicines. Fact sheet: $N^{\circ} 338,2010$. Available at http://www.who.int/mediacentre/ factsheets/fs338/en/. Accessed 29 July 2013.

13. Maxwell S, Walley $\mathrm{T}$, Ferner RE. Using drugs safely. BMJ 2002;324(7343):930-1.

14. World Health Organization. Factsheet: WHO Policy Perspectives on Medicines - Promoting rational use of medicines: core components Geneva WHO, 2002. Available at hppt://www.who.int/entity/medicines/publications/p olicyperspectives/pp m05en.pdf. Accessed 29 July 2013.

doi:10.5455/2319-2003.ijbcp20131019

Cite this article as: Sontakke SD, Budania RJ, Paranjape SG. Evaluation of knowledge, attitude and behavior about rational use of medicines in second year medical students. Int J Basic Clin Pharmacol 2013;2:617-21. 